\title{
The Problems With the Cancellation of the Pledge of Talaq in Religious Courts
}

\author{
Ahmad Jamaludin \\ Lecturer of Marriage Law Faculty of Law of Islam Nusantara University, Indonesia
}

\begin{abstract}
Pledging talaq in the case of divorce lawsuit filed by a husband against the wife in religious courts is substantial. When a husband does not pledge the talaq due to the reconciliation possibility, has positive impact for the marital relationship. However when a husband does not pledge in order to delay or slowing the process thus the divorce remains absence untill the value of pledge invalid and the household bond remains intact, this phenomenom will cause the law uncertainity and injustice for the wife. The purpose of this research is (1) to discover and analyze the regulation of the talaq pledge cancellation in religious court (2) to discover and analyze the legal consequances of the law toward the talaq pledge cancellation with normative juridical method. The results of this research state that (1) the talaq pledge cancellation at religious court regulated in Article 131 of the compilation of Islamic Law but the details of administrative sanctions given to the husband due to the absence of pledging the talaq in order to delay or slowing the process is not regulated and (2) the consequences of the cancellation of the pledge of talaq in religious court can cause legal uncertainty and injustice to the wife due to the absence of divorce thus the houshold bond remains intact and no sanctions are set for the husband. The benefits of this research are to contribute in the form of empirical ideas and findings, specifically regarding the practice of pledging talaq in religious courts.
\end{abstract}

Keywords: The Pledge of Talaq, Marriage Law and Religious Court

\section{Introduction}

Divorce is a concious and deliberate event implemented by husband and wife to end or to dissolve their marriage thus the purpose of happy and longlast familiy becomes aground.

Talaq divorce means a muslim husband who wants to divorce the wife files to the court in order to witness the pledge. The talak pledging has strategic position in the case of divorce lawsuit filed by the husband against the wife in religious court. If the husband does not pledge the talak as determined by the court later than 6 (six) months after the verdict of the religious court regarding the permission of the pledge of divorce that has received legitimate and proper summons from the court, then the right of the husband to pledge the divorce becomes void and his marriage bond remains intact as stated in Article 131 of the Compilation of Islamic Law. If the husband does not pledge the talaq due to reconcilliation with the wife therefore the act have positive impact on the household. However when a husband does not pledge in order to delay or slowing the process thus the divorce remains absence untill the value of pledge void and the household bond remains intact, this phenomenom will cause the law uncertainity and injustice for the wife. Specifically there is no details regulations concerning civil administrative sanctions set against the husband. Despite the process of the legal stage of the event has been completed, yet due to no pledge is pronounced therefore the pledge becomes void. Afterwards, what is the function of the trial (the procedural law of the Religious Courts) 
that has been taken if eventually the absence of the husband can erase all processes and become null and void.

\section{Problem Formulation}

Based on background above, the problems are formulated as: First, how is the regulations of the cancellation of the pledge of talaq in religious court. Second how the concequences of law towards the cancellation of the pledge of talaq in religious court.

\section{Research method}

The method used is normative juridical with primary and secondary data. The data obtained is analyzed quantitatively. This study is a normative legal research done by studying the written law or regulation of existing legal materials. The study is complemented by field research in the form of interviews involving resource persons and related respondents to deepen the answers to problems that have been found in the previous stage. The research literature conducted two phases, before field research and after field research is implemented. Research conducted a study of secondary data, including official legal documents, the results of previous research, and other library materials in these phases.

\section{Results and Discussion}

\subsection{Regulations concerning the cancellation of pledging talak}

The meaning of talak according to language is the release of a bond. And according to Syara 'is the release of a marriage bond. God who unites them and God also gives a way if the marriage is difficult to continue even though in essence God hates a divorce. [1].

The Judiciary is doing its utmost to be able to reconcile couples who want to get divorced to get back together, this is done in every session conducted in accordance with one of the principles of the Marriage Law, which makes it difficult to divorce and contained in article 39 of Marriage Law No. 1 of 1974 The Marriage Law does not prohibit divorce, it is only complicated by its implementation, meaning that there is a possibility of divorce if if it really is unavoidable, it must be done well in front of the Court [2].

The pledge of divorce that will be carried out in court does not necessarily occur when it does not go through the stages determined by the court, or if the reasons for submitting a divorce trial are not considered valid, the trial cannot be held, because such a case can still be found Exit [3].

The term of talaq is unknown in society or positive law. The term that is known and wellspred in society or in positive law is divorce. Divorce is the seperation of a marriage bond between husband and wife who had tied a sacred vow. According to Article 38 Act No. 1 of 1974 states that marriage may end based on three reasons, namely death, divorce, and verdict. Divorce is a way to break the marital relationship between husband and wife that is not caused by the death of one party, but is based on the wishes and wills of the parties [4]. In the Compilation of Islamic Law Article 114 states that: "Seperation due to divorce may occured due to talaq or the lawsuit" [5].

Divorce cases arising from the husband called talaq divorce with the husband as petitioner and a wife as a respondent can ends marriage, described in Article 114 are divided into talaq divorce and lawsuited divorce [6]. In contrast to the Marriage Law which does not recognize 
the term divorce, Article 117 Compilation of Islamic Law to explain what is meant by divorce is the "husband's pledge in the trial courts that bececomes one of the reasons the marriage ends in the manner referred to in Article 129, 130, and 131."

Talaq divorce is if the husband files the lawsuit to the court to divorce the wife, and the wife approves. Article 66 paragraph (1) of Law No. 7 of 1989 concerning Religious Courts (UUPA) states that a Muslim husband who wishes to divorce the wife submits an application to the court to hold a hearing to witness the pledge of divorce.

Article 68 of the UUPA concerning the examination by a court which states that the examination of divorce requests is implemented by a panel of judges no later than 30 (thirty) days after the file or letter of divorce request is registered in the Registrar while the examination for divorce is done in a closed session. In the trial process if reconciliation is not reached, the divorce lawsuit is conducted in a closed session. Then guided by the explanation of article 33 PP No. 9 of 1975, a closed examination in a divorce case included all examinations, including the examination of witnesses [7]. Efforts to reconcile the two parties can not only be taken before the trial begins, but also implemented at each trial, in order to the possibility of reconcilation. The next steps are regulated in Article 70 of the UUPA which reads:

1. The court after concluding that the two parties may no longer be reconciled and the reason for the divorce is sufficient, the court determined that the request was granted.

2. Towards this determination obtaining permanent legal force, the court determines the day of pledge testimony session by summoning the husband and wife or the representatives to attend the hearing.

3. After the determination has permanent legal force, the court determines the day of pledge testimony session by summonning the husband and wife or the representatives to attend the hearing.

4. In the trial the husband or his representative is given special authority in an authentic deed to make a pledge of talaq attended by the wife or the proxy.

5. If the wife has received a legitimate or appropriate call, but does not come to face herself or does not send the representative, the husband or representatives can make a pledge of divorce without the presence of the wife or representatives.

6. If the husband is within a period of 6 (six) months after the day of the pledge of divorce testimony is set, does not come to face himself or not sending his deputy despite the husband has received a legitimate or proper call, therefore the force of the decree is terminated, and divorce cannot be submitted again on the same grounds.

The pledging of the Talak must be pronounced in the case of a divorce lawsuit filed by a husband against his wife in the Religious Court. If a husband does not make a pledge of divorce as determined by the court not later than 6 (six) months after the verdict of the religious court regarding the permission of the pledge of divorce that has received legitimate and proper summons from the court, then the right of the husband to pledge the divorce is void and his marriage bond remains intact as Article 131 of the Compilation of Islamic Law.

There are several reasons and causes the pledge of talaq is not pronounced, namely: (1) The applicant / male party deliberately stalled by not making a pledge thus the divorce does not occur, (2) In the trial process, the wife or the respondent filed a counter-suit (counterclaim) in the form of various claims against the husband or the applicant, and it turns out that all and / or part of the counter-claim is granted, but within 6 (six) months and it turns out the husband and / or the respondent are unable to fulfill it, sometimes the husband and / or applicant does not come again to attend the pledge of witness testimony, (3) the pronouncement of the pledge of divorce is not permitted to the husband or the applicant if the 
fact is found that the husband or the applicant has coverted from the religion of Islam (apostasy) in which the husband or the applicant is not permitted to the person those who are not Muslims to make a pledge of divorce because the beginning of the pronunciation of the Pledge of Divorce is "Basmalah" meanwhile people who are not muslim cannot say "Basmalah" (4). Usually the husband and wife reconcile after the Permanent Legal Force (BHT) verdict that allows the husband and / or applicant to open the hearing to testify the pledge of divorce and it turns out that the husband and wife have reconciled.

Either KHI, or Religious Courts Law and the Marriage Law do not regulate in details the reasons for not saying the pledge of talaq whether intentional or unintentional cause, including civil sanctions. In the case when the pledge is not pronounced whether intentionally or not for 6 months after the divorce verdict, the application will be annulled. Article 131 of the KHI regulates the non-recitation of divorce, with the consequence that the divorce petition will be terminated so that the marriage bond remains intact.

In addition, Article 70 paragraph (6) of the Religion Court Law No. 7 of 1989 contains provisions concerning the abortive power of binding on divorce. If the matter specified in the Article is not fulfilled by the husband, then according to the law, the power of the divorce verdict is void. With the fall of the power of the verdict, divorce is never considered to occur, and the marriage bond is considered to remain and intact.

\subsection{The legal effect of the cancellation of the pledge of talaq}

\subsubsection{There is no legal certainty and injustice for women}

One of the objectives of law is in the normative-dogmative type, assuming that basically the law is solely to create legal certainty. Two of the adherents of this type are, John Austin and van Kan, which originates from positivistic thinking which looks more at law as something more autonomous or law in the form of written regulations. This means that because the law is autonomous so that the legal purpose is solely for legal certainty in legalizing the certainty of one's rights and obligations. Van Kan argues that the purpose of the law is to safeguard every human interest so as not to be disturbed and guaranteed certainty [8].

Legal certainty in society is needed for the sake of order and justice. Legal uncertainty will cause chaos in people's lives, and every member of the community will act with each other as they please and act vigilantly. This kind of existence makes life in an atmosphere of social chaos [9].

In addition to uncertainty, other legal objectives are solely to achieve justice. According to the Kamus Besar Bahasa Indonesia (Indonesian Big Dictionary), justice means "not biased, treating or weighing something in the same and similar way and not limping or siding with the right; hold on to the truth.

Causes that aborts the power of the divorce verdict is dependent on the factor of the absence of the husband in implementing the pledge of divorce on the appointed day of the hearing, connected with a period of 6 (six) months. If the Religious Court has established a trial day for pledge of divorce, the husband or his representative do not come and it has lasted 6 (six) months, according to the law the power of the verdict falls. The verdict does not have the power to bind the husband and wife again and also has no legal consequences for their marriage.

Not pledging the talaq and letting the lawsuit falls in order to delay the process of divorce or deliberately stalling the time of divorce is an injustice condition for the woman or defendants. Because the process of filing the lawsuit until the verdict takes time. Obviously, if a long process has been passed, but when the pledge is not attended by the applicant thus verdict has never existed according to judges, or the marital relationship between the husband 
and wife is considered intact. This is what causes problems and creates a sense of injustice and legal uncertainty for the wife.

Thus the result of a legal decision that is not followed by a talaq pledge is a verdict that by a judge in the religious court considers that the verdict has never existed and the divorce is deemed to have never occurred, that the husband and wife's relationship is still considered intact by law because verdict by religious court considered the event have never existed.

\subsubsection{Filing the counter-claim by the Wife}

The cancellation of the pledging by the husband in the divorce case will result in the fall of a case thus for legal certainty when the marriage bond can no longer be maintained, the only way is for the wife to file a divorce claim against the husband. The lawsuit process is called Lawsuited Divorce, namely the lawsuit filed by the wife whose petition requested to the Religious court to end the marriage of the plaintiff with the defendant.

Filing a divorce claim that is filed by a wife or proxy to the court whose jurisdiction covers the wife's residence. Because in the lawsuited divorce case there is no pledging of talaq in the trial process.

The term of lawsuit divorce is contained in the Republic of Indonesia Law Number 7 of 1989 concerning Religious Courts, which has been amended into Republic of Indonesia Law Number 3 of 2006 and Republic of Indonesia Law Number 50 of 2009. Thus what is meant by a divorce in this research is a wife or who represented her filed for divorce against her husband to the local Religious Court.

The definition of divorce according to special Islamic law compilation in article 132 paragraph (1) is a divorce lawsuit filed by the wife or the proxy at the Religious Court whose jurisdiction is the place of residence of the plaintiff unless the wife leaves the joint residence without the permission of the husband [10].

The meaning of the lawsuited divorce is that the wife takes the initiative to divorce her husband for various reasons, one of which is that the husband is stalling for time to get a divorce. So that the wife has her own right to determine the marital status and does not depend on the marital status on the husband. Because in classical fiqh literature, more space is provided for men to be positioned as parties who have exclusive rights to divorce the wives.

Divorce lawsuit is an effective step for the wife to end the marital relationship, when the husband is deemed to no longer fulfill his rights and obligations which should be fulfilled in implementing the household ark or the husband deliberately stalling for the divorce to not occur. Moreover, the absence of a pledge of divorce in a divorce claim by the husband makes the divorce lawsuit more certain and does not depend on the husband's pronouncement of divorce.

\section{Conclusion}

Cancellation of talaq pledging is regulated in article 131 of the Compilation of Islamic Law. The cancellation of the reading of the pledge in order to stall the process, apostate husband and not being able to pay the wife's demands, cause a problem that gives rise to a sense of injustice and legal uncertainty for the wife. To anticipate the cancellation of the talak pledging, the wife filed a counterclaim lawsui, namely a divorce claim.

\section{Suggestions}

There is a need for sanctions against the Petitioners who cancel the pledge of divorce in order to stall the divorce process. There is a need to be regulated in details related to the pledge of 
talaq, as well as the legal consequences when the reading of the pledge is canceled by the husband.

\section{References}

[1] Putri, Dinna Keumala. Implementasi Mediasi Pada Perkara Cerai Talak dalam hal ketidak hadiran tergugat di Pengadilan Agama Pekanbaru. Pekanbaru: JOM Fakultas Hukum, Vol. III Nomor 2, p. 5 (2016)

[2] Lubi, Rusdi Rizki. "Mut'a Livelihoods Implementation On Divorce Case Of Talak Qabla Dukhul" Bogor: Mizan Jurnal Ilmu Syariah, Vol. 3 nomor 2, pp. 237-252. ISSN:2089-032X- 240 (2015).

[3] Barmawi, Mohammad. "Ikrar Talak Pengadilan Agama", Jember: Jurnal Qalamuna, Vol. 1 Nomor 2, pp. 191-212 (2016).

[4] Bintania, Aris. Hukum Acara Pengadilan Agama dalam Kerangka Fiqh al-Qadha, Jakarta: Raja Grafindo Persada, p. 151 (2012).

[5] Saekan and Effendi, Erniati. Sejarah Penyusunan Kompilasi Hukum Islam, Surabaya: Arloka Surabaya, p. 106 (1997).

[6] Nuruddin, Amiur and Tarigan, Azhari Akmal. Hukum Perdata Islam di Indonesia, Jakarta: Kencana, p. 220 (2006).

[7] M. Yahya Harahap. Kedudukan Kewenangan dan Acara Peradilan Agama. Jakarta: Sinar Grafika, p. 222 (2005).

[8] Mas, Marwan. Pengantar Ilmu Hukum. Bogor: Ghalia Indonesia, p. 84 (2011).

[9] Harahap, M.Yahya. Pembahasan,Permasalahan dan Penerapan KUHAP. Jakarta : Sinar Grafika, p. 76 (2006).

[10] Manan, Abdul and Fauzan, M. Pokok-Pokok Hukum Perdata Wewenang Peradilan Agama . Jakarta : RajaGrafindo Persada, p. 51 (2002). 